\title{
ANN modelling approach for predicting SCC properties - Research considering Algerian experience. Part I. Development and analysis of models
}

\author{
Sahraoui $\mathrm{M}^{*}$, Bouziani T
}

Structures Rehabilitation and Materials Laboratory (SREML), University Amar Telidji, Laghouat, Algeria.

* Corresponding Author: med.sahraoui@lagh-univ.dz

Received: 20-08-2020

Accepted: 08-10-2020

Abstract. This paper presents research on the use of artificial neural networks (ANNs) to predict fresh and hardened properties of self compacting concrete (SCC) made with Algerian materials. A multi-layer perceptron network with 5 nodes, 12 inputs, and 5 outputs is trained and optimized using a database of 167 mixtures collected from literature. The inputs for the ANN models are ordinary Portland cement $(\mathrm{Cm})$, polycarboxylate ether superplasticizer $(\mathrm{Sp})$, river sand (RS), crushed sand (CS), dune sand (DS), Gravel 3/8 $\left(\mathrm{G}_{1}\right)$, Gravel 8/15 $\left(\mathrm{G}_{2}\right)$, Water (W), Limestone filler (Lim), Marble powder (MP), blast furnace slag (Slag) and natural pozzolan (Pz). Instead, Slump flow (Slump), V-funnel, L-Box, static stability (Pi) and 28 days compressive strength (Rc28) were the outputs of the study. Results indicate that ANN models for data sets collected from literature have a strong potential for predicting 28 days compressive strength. Slump flow, V-funnel time and L-Box ratio could be moderately identified while an acceptable prediction has been obtained for static stability. Results have also confirmed by statistical parameters, Regression plots and residual analysis.

Key words: Artificial neural networks, self compacting concrete, Algerian materials, fresh and hardened properties, prediction.

\section{Introduction}

Self-compacting concrete (SCC) is a high flowable concrete that can flow readily under its selfweight (Okamura \& Ouchi, 2003). The development of a SCC formulation is much more complex according to its sensitivity to small variations of mix proportions such as the proportion of water, cement, superplasticizer, aggregates and supplementary cementitious materials. Assessing the role of mix constituents considered as a key factor for an adequate formulation.

Nowadays, several studies have been using various methods such as statistical methods, analytical modelling, and artificial intelligence for predicting fresh and hardened properties of SCC based on various components (Getahun et al., 2018).

ANNs technique is a statistical method that advance the accuracy using extensive experimental data and neural networks algorithms in order to create an appropriate model which could solve complex problems (Ahmadi et al., 2017). In addition, this method could value previous works and making them as mathematical models, which may help to predict properties of concrete mixtures before conducting laboratory experiments.

Several researchers are recently interested to predict SCC properties using ANNs. Sonebi et al. (2016) investigate the feasibility of using ANNs for prediction the fresh properties of SCC, they demonstrate the efficiency of ANNs to predict the filling ability, flowability and passing ability with good accuracy. Abu Yaman et al. (2017) reported that mix proportioning of SCC mixes could be performed using the trained neural network which in turn assures its effectiveness. Douma et al. (2017) indicate that ANNs have strong potential as a feasible tool for predicting accurately the properties of SCC incorporating fly ash. Asteris et al. (2016) demonstrate the promising potential of ANN for the reliable and robust approximation of the 28 days compressive strength of admixture-based self compacting concrete. 
The main objective of this study is to develop ANN models for predicting the fresh and hardened states of SCC made with Algerian components and based on experimental data gathered from literature.

\section{Literature review}

Several studies have been done to evaluate the possibility of formulating self compacting concrete based on local materials. Boukendakdji et al. (2009) evaluate the effect of Algerian slag on the properties of fresh and hardened SCC. Belaidi et al. (2012) study the influence of formulation parameters on rheological, mechanical and durability of SCC, through partial substitution of cement by natural pozzolana of Beni-saf and marble powder residue industry shaping and polishing marble. (Benabed, 2014) examines the influence of various types of sand with different morphologies and origins on the fresh and hardened properties of self compacting concrete. (Bouziani, 2013) provides a statistical approach to evaluate the effect of different kind of sands on the properties of SCC.

Boukhelkhal et al. (2015) study the effect of Algerian mineral admixtures (blast furnace slag, natural pozzolana and limestone fillers) on stability and rheology of SCC. Boukhelkhal et al. (2016) evaluate the effect of incorporating the marble powder as a supplementary cementitious material on rheological and mechanical properties of self compacting concrete. (Nécira, 2018) develops a series of high-performance self-compacting concrete using quarry sand, dune sand, limestone filler, natural pozzolana and granulated slag. Sahraoui and Bouziani. (2019 a,b) study the effects of mixture components and sand contents on rheological and hardened properties of self compacting concrete.

Benyamina et al. (2019) investigate the influence of quarry limestone fines from manufactured crushed sand on rheological, mechanical and durability properties of SCC. Skender et al. (2019) assess the effects of various amounts of Algerian limestone filler, which is expected to modify the physical, mechanical and transport properties of SCC. Ouldkhaoua et al. (2019) examine how the use of metakaolin powder and catodique ray tube glass will affect the rheological properties of self-compacting concrete. Laidani et al. (2020) study the effect of using calcined bentonite as partial replacement of ordinary Portland cement on the sustainability of SCC. YH Aissa et al. (2020) explore the possibility of using calcareous tuff in SCC production.

Details of all mixes collected from literature are resumed in Table 1. It should be noted that the above-mentioned works were selected on the basis of the following common components:

- Ordinary Portland Cement (CEMI 42.5);

- Third generation polycarboxylate ether-based (Medaflow 30 and 145);

- Three types of sand (RS, CS and DS);

- Limestone-type gravels (3/8) and (8/15);

- Four mineral admixtures (Lime stone, Marble powder, Slag and Pozzolan).

It is also worth noting that there are about forty other researches have reported the use of local materials to formulate SCC, but these studies are not compatible with the selected researches in terms of cement, superplasticizer types and the use of viscosity modifying agent (VMA). 
Table 1: data sets collected from literature

\begin{tabular}{|c|c|c|c|c|c|c|c|c|c|c|c|c|}
\hline \multirow[b]{2}{*}{ References } & \multicolumn{12}{|c|}{ Content } \\
\hline & $\begin{array}{c}\text { Cement } \\
\left(\mathrm{Kg} / \mathrm{m}^{3}\right)\end{array}$ & $\begin{array}{c}\mathrm{RS} \\
\left(\mathrm{Kg} / \mathrm{m}^{3}\right) \\
\end{array}$ & $\begin{array}{c}\mathrm{CS} \\
(\mathrm{Kg} / \mathrm{m} 3) \\
\end{array}$ & $\begin{array}{c}\mathrm{DS} \\
\left(\mathrm{Kg} / \mathrm{m}^{3}\right)\end{array}$ & $\begin{array}{c}\text { Gravel } \\
3 / 8(\mathrm{G} 1)\end{array}$ & $\begin{array}{c}\text { Gravel } \\
8 / 15 \text { (G2) }\end{array}$ & $\mathrm{W} / \mathrm{P}$ & Sp (\%) & $\begin{array}{l}\operatorname{Lim} \\
(\%)\end{array}$ & $\begin{array}{l}\text { MP } \\
(\%) \\
\end{array}$ & $\begin{array}{l}\text { Slag } \\
(\%)\end{array}$ & $\begin{array}{c}\mathrm{Pz} \\
(\%) \\
\end{array}$ \\
\hline Boukendakdji et al. (2009) & $352-465$ & 867 & 0 & 0 & 280 & 560 & 0.4 & $1.2-2$ & 0 & 0 & $10-25$ & 0 \\
\hline Belaidi et al. (2012) & $285-475$ & 886 & 0 & 0 & 277 & 553 & 0.4 & 0.9 & 0 & $5-30$ & 0 & $5-25$ \\
\hline (Bouziani, 2013) & 380 & 848 & 0 & 0 & 880 & 0 & 0.4 & 1.6 & 0 & 52.37 & 0 & 0 \\
\hline (Benabed, 2014) & 475 & $0-886$ & $0-886$ & $0-886$ & 277 & 553 & 0.4 & $0.9-1.5$ & 0 & 0 & 0 & 0 \\
\hline Boukhelkhal et al. (2015) & 404-467 & 0 & 541 & 360 & 401 & 401 & 0.42 & 1.6 & $0-15$ & 0 & $0-15$ & $0-15$ \\
\hline Boukhelkhal et al. (2016) & $376-470$ & 882.9 & 0 & 0 & 277 & 553 & 0.4 & 0.9 & 0 & $0-20$ & 0 & 0 \\
\hline Nécira et al. (2017) & 400 & $0-770.89$ & $0-780$ & $0-776.84$ & 385.45 & 385.45 & 0.35 & 1.5 & 37.5 & 0 & 0 & 0 \\
\hline (Nécira, 2018) & 251-501 & 821.69 & 0 & 0 & 432.9 & 432.9 & 0.32 & 0.6 & $0-50$ & 0 & $0-50$ & $0-50$ \\
\hline \multirow{2}{*}{ Sahraoui and Bouziani. (2019 a,b) } & 420 & $754-1041$ & 0 & 0 & $0-874.5$ & $0-874.5$ & 0.37 & 0.9 & 0 & $0-25$ & 0 & 0 \\
\hline & 420 & $0-877.15$ & $0-877.15$ & $0-877.15$ & 350.86 & 526.29 & 0.38 & 0.95 & 0 & 20 & 0 & 0 \\
\hline Benyamina et al. (2019) & 490 & 0 & $480-600$ & 323 & 443 & 295 & 0.4 & 1.4 & $0-25$ & 0 & 0 & 0 \\
\hline Skender et al. (2019) & 481-490 & 0 & $450-600$ & 323 & 443 & 295 & 0.4 & 1.4 & $0-25$ & 0 & 0 & 0 \\
\hline Ouldkhaoua et al. (2019) & 469.59 & 909.78 & 0 & 0 & 329 & 494 & 0.4 & 0.8 & 0 & 0 & 0 & 0 \\
\hline Laidani et al. (2020) & 469.59 & 906.22 & 0 & 0 & 266.1 & 536.06 & 0.4 & 0.8 & 0 & 0 & 0 & 0 \\
\hline YH Aissa et al. (2020) & 560 & 0 & 960 & 0 & 270 & 545 & 0.4 & 0.5 & 0 & 0 & 0 & 0 \\
\hline
\end{tabular}




\section{Methodology}

A total of 167 SCC mixtures collected from literature was used for the training and validation of the ANNs. These models were built with 5 Hidden nodes and validated using a random holdback of $33 \%$ of the dataset in order to estimate parameters and assess the predictive ability of models. The equation and structure of the ANN models used in this research are expressed in Equation 1 and Figure 1.

$$
\begin{aligned}
\mathrm{Y}= & \mathrm{A}_{0}+\mathrm{A}_{1} \times \operatorname{TanH}\left(0.5 \times\left(\mathrm{B}_{1}+\mathrm{C}_{1.1} \times \mathrm{Sp}+\mathrm{C}_{1.2} \times \mathrm{Cm}+\cdots+\mathrm{C}_{1.12} \times \mathrm{Pz}\right)\right) \\
& +\cdots+\mathrm{A}_{5} \times \operatorname{TanH}\left(0.5 \times\left(\mathrm{B}_{5}+\mathrm{C}_{5.1} \times \mathrm{Sp}+\mathrm{C}_{5.2} \times \mathrm{Cm}+\cdots+\mathrm{C}_{5.12} \times \mathrm{Pz}\right)\right)
\end{aligned}
$$

Where $\mathrm{Ai}, \mathrm{Bi}, \mathrm{Ci}, \mathrm{j}$ are the model coefficients (Table 2) and TanH is the hyperbolic tangent function which represent the activation function investigated in this work and is defined as:

$$
\operatorname{TanH}(x)=\frac{e^{2 x}-1}{e^{2 x}+1}
$$

The training, validation, and test sets are created by subsetting the original data into parts. For this purpose, a Holdback method was selected in order to divide the original data into training and validation sets randomly. It could also specify the proportion of the original data to use as the validation set (JMP, 2020). It should be noted that a higher number of nodes results in more effective training, increases model complexity and processing time which required to enhance the computational power.

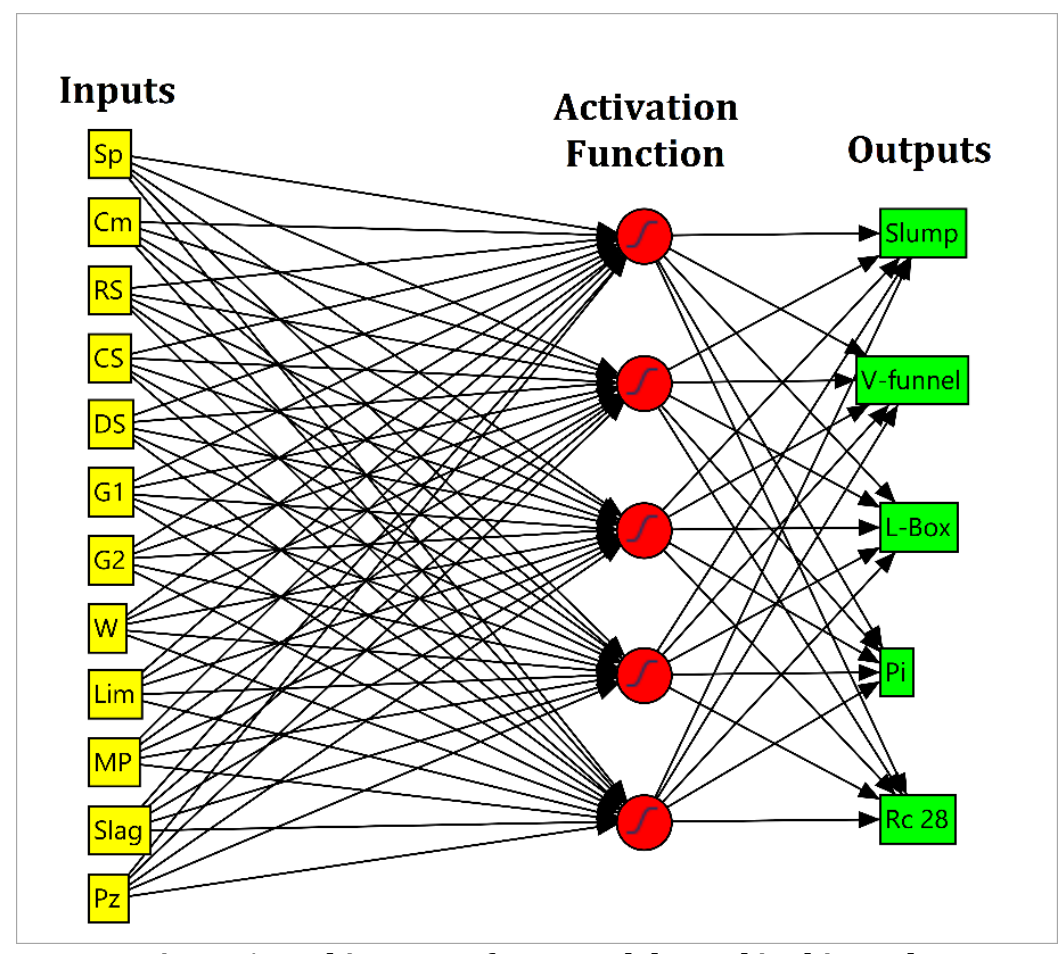

Figure 1: Architecture of ANN models used in this study 


\section{Results and discussion}

Parameters estimates and model coefficients of the ANN models used in this research are shown in Tables 2 and 3 respectively. Five different statistical parameters have been employed for judging the performance of actual and predicted data including: the squared Pearson correlation coefficient $\left(\mathrm{R}^{2}\right)$, root mean square error (RMSE), the mean absolute deviation (MAD), the error sums of squares (SSE) and the sum of the frequencies (Sum Freq).

It can be seen that all models performed well and provided very good correlation coefficients $\left(\mathrm{R}^{2}>0.8\right.$ for training and $\mathrm{R}^{2}>0.7$ for validation ) except the predicted static stability $\mathrm{Pi}\left(\mathrm{R}^{2}\right.$ close to 0.7 for training and 0.64 for validation), this decline may be attributed to the high sensitivity of SCC when there have been a small variation of mix proportions (Thakre et al. 2017) Instead, results obtained in compressive strength at 28 days were correlated a high level $\left(\mathrm{R}^{2}\right.$ close to 0.97 for training and 0.89 for validation), which lead to conclude that ANNs were highly successful in learning and predicting the 28 days compressive strength. Similar tendency has been observed by (Malagavelli \& Manalel, 2014) (Asteris et al., 2016) (Saha et al., 2017).

RMSE was calculated in order to measure the differences between actual and predicted values, a lower value of RMSE have been obtained which indicate the good prediction performance of the obtained models. Smaller values of MAD confirm once more that ANNs can better fit the data used in this experiment. The high SSE values of Pi and L-Box indicate a large degree of variability within the data set, while the lower SSE for Rc28 reveals that the data does not vary considerably from the mean value, confirming that the results created by the ANNs were very close to those of actual values.

Figures 2 to 6 provide the regression values for all actual and predicted data. It is obvious that Rc28 achieves the most reliable prediction while acceptable regressions have been registered for Slump and V-funnel. Instead, regression values for Pi and even for L-Box were moderate as report statistics have demonstrated. This confirms that the obtained models were able to reproduce the experimental results with high or acceptable accuracy.

Residual by predicted plot for all models are presented in Figure 7. From this figure, it can be revealed that there aren't any clear patterns in general. The points in a residual plot of Slump and Rc28 are randomly dispersed around the horizontal axis and they can be categorized as very good with a random error and this is a further justification of the previous results. Residuals of $\mathrm{V}$-funnel, L-Box and Pi appear clustered on the horizontal axis, confirming once again that the functional part of models does not fit the data perfectly.

Table 2: Details report statistics

\begin{tabular}{|c|c|c|c|c|c|c|}
\hline \multicolumn{2}{|c|}{} & Slump & V-funnel & L-Box & Pi & Rc28 \\
\hline \multirow{4}{*}{ Training } & Rsquared (R 2 ) & 0.880517 & 0.897185 & 0.815892 & 0.696938 & 0.968663 \\
\cline { 2 - 7 } & RMSE & 2.527693 & 1.601559 & 7.183838 & 4.496816 & 2.78906 \\
\cline { 2 - 7 } & MAD & 1.983659 & 1.014633 & 5.335368 & 3.437899 & 2.013808 \\
\cline { 2 - 7 } & SSE & 709.2046 & 223.1542 & 5676.828 & 1900.807 & 700.097 \\
\cline { 2 - 7 } & Sum Freq & 111 & 87 & 110 & 94 & 90 \\
\hline \multirow{4}{*}{ Validation } & $\mathrm{R}^{2}$ & 0.701792 & 0.785027 & 0.682712 & 0.641965 & 0.889876 \\
\cline { 2 - 7 } & RMSE & 4.628809 & 2.934053 & 9.577025 & 5.824216 & 4.832185 \\
\cline { 2 - 7 } & MAD & 3.659927 & 1.732885 & 6.862325 & 3.73383 & 3.629195 \\
\cline { 2 - 7 } & SSE & 1199.849 & 378.7813 & 5136.287 & 1594.31 & 1074.101 \\
\cline { 2 - 7 } & Sum Freq & 56 & 44 & 56 & 47 & 46 \\
\hline
\end{tabular}


Table 3: Model coefficients of responses

\begin{tabular}{|c|c|c|c|c|c|}
\hline \multirow{2}{*}{ Parameter } & \multicolumn{5}{|c|}{ Estimate } \\
\hline & Slump & V-funnel & L-box & $\mathrm{Pi}$ & Rc28 \\
\hline $\mathrm{A}_{0}$ & 63.28388 & 15.14357 & 69.56581 & 26.30666 & 55.77593 \\
\hline $\mathrm{A}_{1}$ & 9.762795 & 15.6597 & 18.5131 & 2.624009 & -3.62263 \\
\hline $\mathrm{A}_{2}$ & -10.9652 & -9.84658 & $\begin{array}{l}-18.601 \\
\end{array}$ & -2.4258 & 9.297474 \\
\hline $\mathrm{A}_{3}$ & 10.04468 & 1.301451 & -11.8994 & -1.53255 & -15.5049 \\
\hline $\mathrm{A}_{4}$ & -4.89305 & -15.6859 & 11.33388 & -0.35976 & 4.938328 \\
\hline $\mathrm{A}_{5}$ & -12.7381 & 19.00461 & -15.1506 & -18.9019 & -17.2991 \\
\hline $\mathrm{B}_{1}$ & -23.5887 & -3.63521 & -28.7153 & 150.8015 & -10.2121 \\
\hline $\mathrm{B}_{2}$ & 16.00778 & -0.46792 & 12.46874 & 35.01113 & -8.83419 \\
\hline $\mathrm{B}_{3}$ & -15.9981 & -0.34531 & 16.55757 & 5.528856 & -127.601 \\
\hline $\mathrm{B}_{4}$ & -21.0522 & -0.16354 & -27.9107 & -106.68 & 11.75059 \\
\hline $\mathrm{B}_{5}$ & 0.006721 & 1.650363 & -11.9844 & 30.77949 & 27.11841 \\
\hline $\mathrm{C}_{1.1}$ & 0.274386 & 0.051259 & -6.44301 & -5.33024 & 2.106865 \\
\hline $\mathrm{C}_{1.2}$ & 0.015749 & -0.00366 & 0.057676 & -0.04392 & 0.020887 \\
\hline $\mathrm{C}_{1.3}$ & 0.002319 & 0.000106 & 0.002042 & 0.000492 & 0.000587 \\
\hline $\mathrm{C}_{1.4}$ & 0.011904 & -0.00028 & 0.014763 & -0.02168 & 0.002026 \\
\hline $\mathrm{C}_{1.5}$ & 0.005066 & $-2.26 \mathrm{E}-05$ & -0.01826 & 0.048427 & -0.00046 \\
\hline $\mathrm{C}_{1.6}$ & -0.01559 & 0.00128 & -0.00397 & -0.009 & 0.00334 \\
\hline $\mathrm{C}_{1.7}$ & 0.00682 & -0.00101 & -0.01635 & -0.00989 & -0.00107 \\
\hline $\mathrm{C}_{1.8}$ & 0.059329 & 0.022315 & 0.242906 & -0.52765 & -0.04285 \\
\hline $\mathrm{C}_{1.9}$ & -0.00568 & 0.006374 & -0.0087 & 0.038518 & -0.00993 \\
\hline $\mathrm{C}_{1.10}$ & 0.021006 & 0.002181 & 0.034455 & -0.10915 & -0.01066 \\
\hline$C_{1.11}$ & 0.037648 & 0.001147 & -0.08038 & 0.233543 & -0.04839 \\
\hline $\mathrm{C}_{1.12}$ & 0.028369 & 0.007646 & 0.097666 & -0.01825 & 0.028028 \\
\hline $\mathrm{C}_{2.1}$ & -0.16161 & -0.11075 & -0.55608 & 0.267028 & -0.33354 \\
\hline $\mathrm{C}_{2.2}$ & 0.023716 & $3.44 \mathrm{E}-05$ & -0.03596 & -0.01568 & 0.054679 \\
\hline $\mathrm{C}_{2.3}$ & 0.000134 & 0.001165 & -0.0 & -0.00347 & -0.00446 \\
\hline $\mathrm{C}_{2.4}$ & 0.003594 & -0.0007 & 0.000406 & 0.003751 & 0.000753 \\
\hline $\mathrm{C}_{2.5}$ & -0.00305 & -0.00363 & -0.00323 & -0.00531 & -0.00482 \\
\hline $\mathrm{C}_{2.6}$ & -0.02423 & 0.000267 & 0.003523 & -0.00161 & 0.007988 \\
\hline $\mathrm{C}_{2.7}$ & -0.0031 & 0.000168 & 0.009704 & 0.005639 & 0.014136 \\
\hline $\mathrm{C}_{2.8}$ & -0.08759 & 0.004299 & 0.013601 & -0.16777 & -0.09512 \\
\hline $\mathrm{C}_{2.9}$ & 0.020337 & -0.00544 & -0.0605 & -0.00729 & 0.001271 \\
\hline$C_{2.10}$ & 0.004044 & 0.002177 & 0.045792 & -0.01218 & 0.005885 \\
\hline $\mathrm{C}_{2.11}$ & -0.01047 & -0.0107 & -0.04933 & 0.064607 & 0.027733 \\
\hline $\mathrm{C}_{2.12}$ & -0.08962 & -0.0 & -0.0 & 976 & 0.00 \\
\hline $\mathrm{C}_{3.1}$ & -0.90575 & 0.021695 & -0.57513 & 0.047839 & 2.712765 \\
\hline $\mathrm{C}_{3.2}$ & 0.012898 & 0.000114 & 0.024287 & -0.00641 & -0.02383 \\
\hline $\mathrm{C}_{3.3}$ & 0.003106 & -0.00004 & 0.000832 & -0.00491 & 0.003437 \\
\hline $\mathrm{C}_{3.4}$ & 0.004608 & 0.000185 & 0.011968 & 0.000208 & -0.00403 \\
\hline $\mathrm{C}_{3.5}$ & -0.00225 & -0.00015 & -0.00801 & 0.006895 & -0.00104 \\
\hline $\mathrm{C}_{3.6}$ & -0.01189 & $-1.82 \mathrm{E}-05$ & -0.0009 & 0.005767 & -0.02916 \\
\hline $\mathrm{C}_{3.7}$ & -0.00656 & $-8.42 \mathrm{E}-05$ & 0.001794 & 0.001471 & 0.014449 \\
\hline $\mathrm{C}_{3.8}$ & 0.110108 & 0.001288 & -0.14507 & -0.02886 & 0.681383 \\
\hline $\mathrm{C}_{3.9}$ & 0.074988 & 0.000322 & 0.001063 & 0.01544 & 0.034961 \\
\hline $\mathrm{C}_{3.10}$ & 0.001166 & -0.00015 & -0.05332 & -0.01557 & -0.03789 \\
\hline$C_{3.11}$ & -0.01852 & -0.00042 & -0.01343 & -0.03729 & -0.30774 \\
\hline $\mathrm{C}_{3.12}$ & -0.09811 & -0.00036 & 0.068436 & 0.016709 & -0.00431 \\
\hline $\mathrm{C}_{4.1}$ & -0.56855 & 0.060285 & -0.04676 & 0.102512 & -0.56029 \\
\hline $\mathrm{C}_{4.2}$ & -0.00058 & -0.00231 & 0.037324 & 0.074527 & 0.045114 \\
\hline $\mathrm{C}_{4.3}$ & -0.00196 & 0.000563 & -0.00744 & -0.00271 & 0.004801 \\
\hline
\end{tabular}




\begin{tabular}{|c|c|c|c|c|c|}
\hline \multicolumn{7}{|c|}{ Table3: continued } \\
\hline \multirow{2}{*}{ Parameter } & \multicolumn{5}{|c|}{ Estimate } \\
\cline { 2 - 6 } & Slump & V-funnel & L-box & Pi & Rc28 \\
\hline $\mathrm{C}_{4.4}$ & 0.00607 & -0.0001 & 0.022628 & 0.012973 & 0.008234 \\
\hline $\mathrm{C}_{4.5}$ & -0.00017 & -0.00148 & -0.00307 & -0.00569 & -0.01172 \\
\hline $\mathrm{C}_{4.6}$ & -0.00346 & -0.00103 & -0.00872 & -0.00193 & -0.00427 \\
\hline $\mathrm{C}_{4.7}$ & -0.00344 & 0.000349 & 0.003323 & 0.003267 & -0.00517 \\
\hline $\mathrm{C}_{4.8}$ & 0.141922 & 0.007608 & 0.081171 & 0.36632 & -0.12896 \\
\hline $\mathrm{C}_{4.9}$ & -0.01441 & 0.011606 & -0.09656 & -0.00705 & 0.021165 \\
\hline $\mathrm{C}_{4.10}$ & 0.019381 & -0.00544 & -0.00735 & 0.050952 & 0.005363 \\
\hline $\mathrm{C}_{4.11}$ & 0.034617 & 0.005238 & 0.100924 & 0.033341 & -0.011 \\
\hline $\mathrm{C}_{4.12}$ & -0.04773 & 0.00696 & 0.038846 & -0.0471 & 0.056323 \\
\hline $\mathrm{C}_{5.1}$ & -0.31598 & -0.11879 & -1.5101 & -1.67961 & -3.91819 \\
\hline $\mathrm{C}_{5.2}$ & -0.0297 & 0.005039 & -0.00144 & 0.060703 & -0.02201 \\
\hline $\mathrm{C}_{5.3}$ & -0.00974 & 0.001052 & -0.00261 & -0.02415 & -0.00348 \\
\hline $\mathrm{C}_{5.4}$ & -0.00267 & -0.0001 & 0.011369 & -0.03148 & 0.002148 \\
\hline $\mathrm{C}_{5.5}$ & -0.00296 & -0.00267 & 0.007953 & -0.02841 & 0.007107 \\
\hline $\mathrm{C}_{5.6}$ & 0.000888 & -0.0017 & -0.00106 & 0.076022 & -0.01745 \\
\hline $\mathrm{C}_{5.7}$ & 0.00423 & 0.001507 & 0.009059 & -0.00798 & 0.035716 \\
\hline $\mathrm{C}_{5.8}$ & 0.075789 & -0.01946 & 0.026686 & -0.20353 & -0.02288 \\
\hline $\mathrm{C}_{5.9}$ & 0.014454 & 0.004378 & 0.060278 & 0.022536 & -0.03866 \\
\hline $\mathrm{C}_{5.10}$ & -0.01043 & -0.00204 & 0.057819 & 0.025281 & -0.00018 \\
\hline $\mathrm{C}_{5.11}$ & -0.01188 & 0.006042 & 0.072845 & 0.026894 & 0.115404 \\
\hline $\mathrm{C}_{5.12}$ & 0.015081 & 0.003512 & 0.005938 & 0.076111 & 0.043143 \\
\hline
\end{tabular}
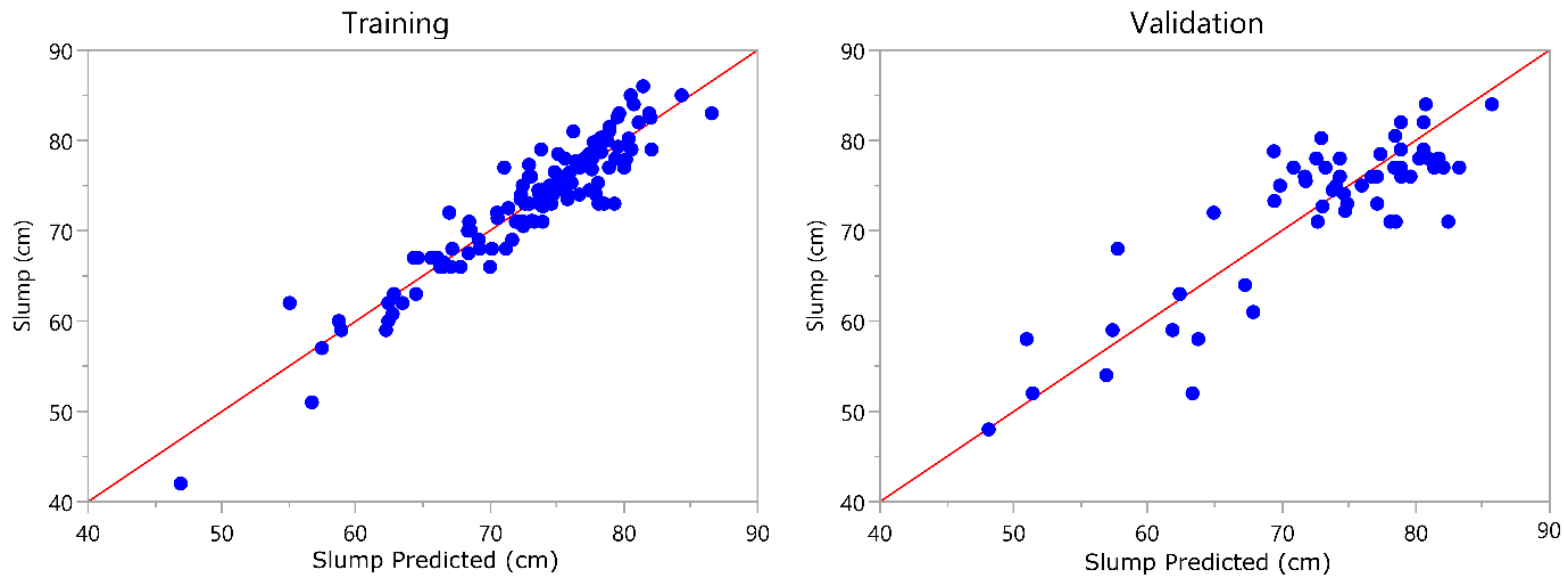

Figure 2: Regression for training and validation data results of Slump 

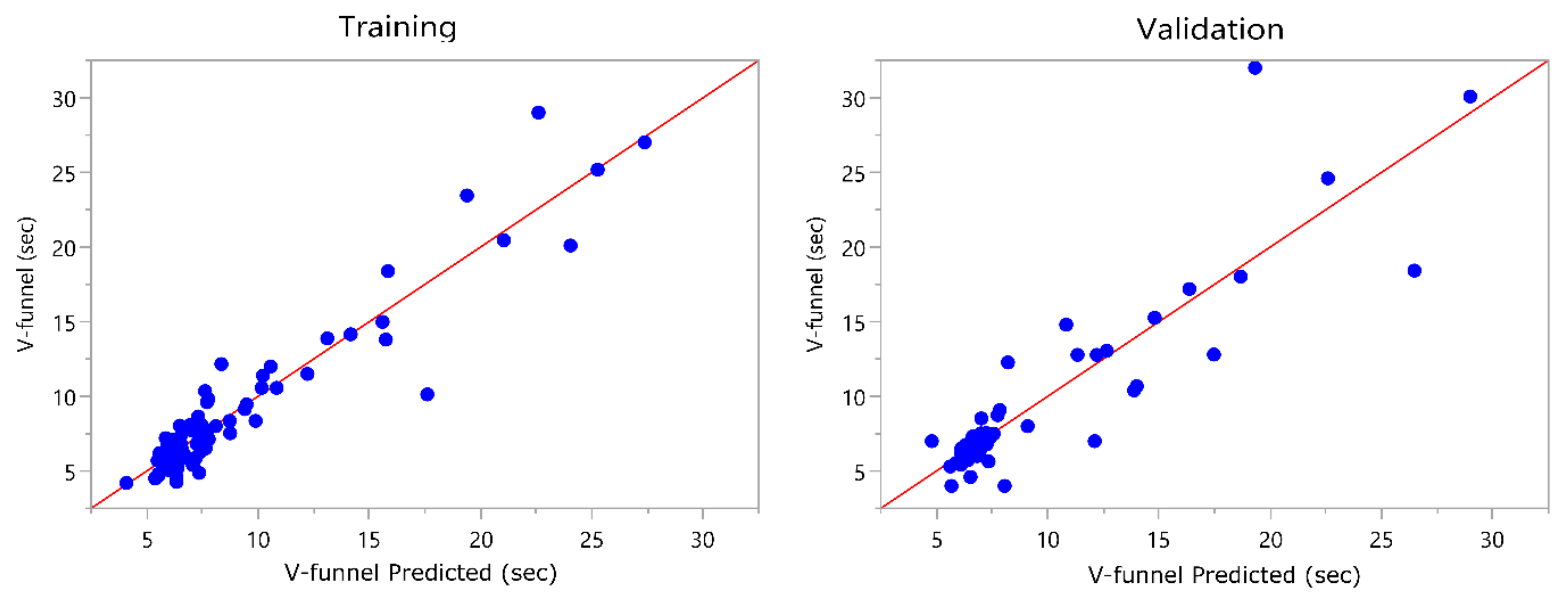

Figure 3: Regression for training and validation data results of $V$-funnel
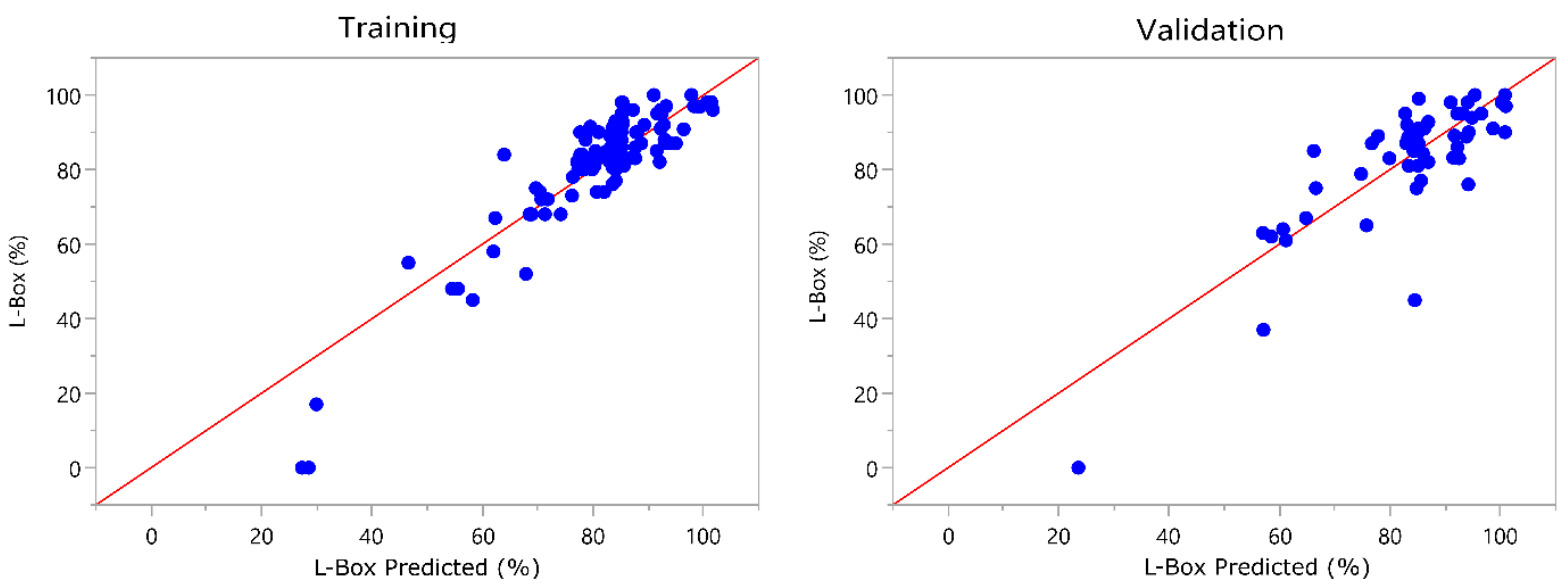

Figure 4: Regression for training and validation data results of L-Box
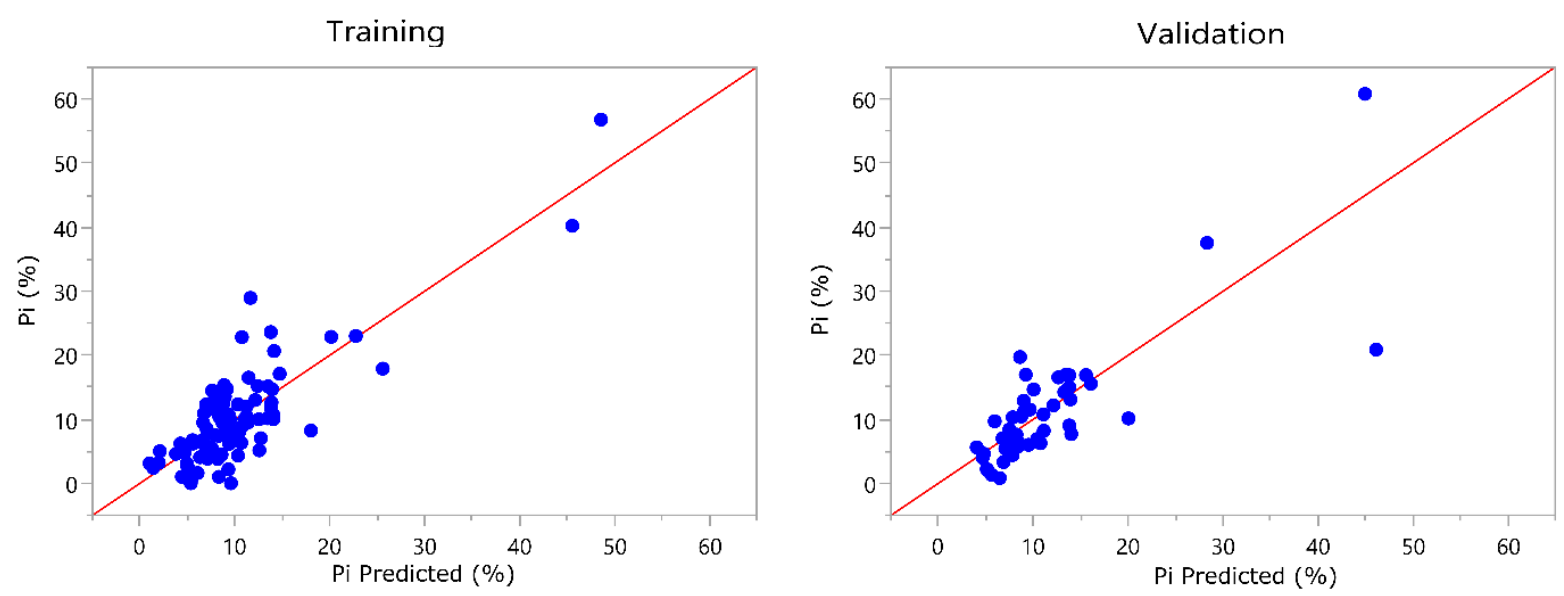

Figure 5: Regression for training and validation data results of $\mathrm{Pi}$ 

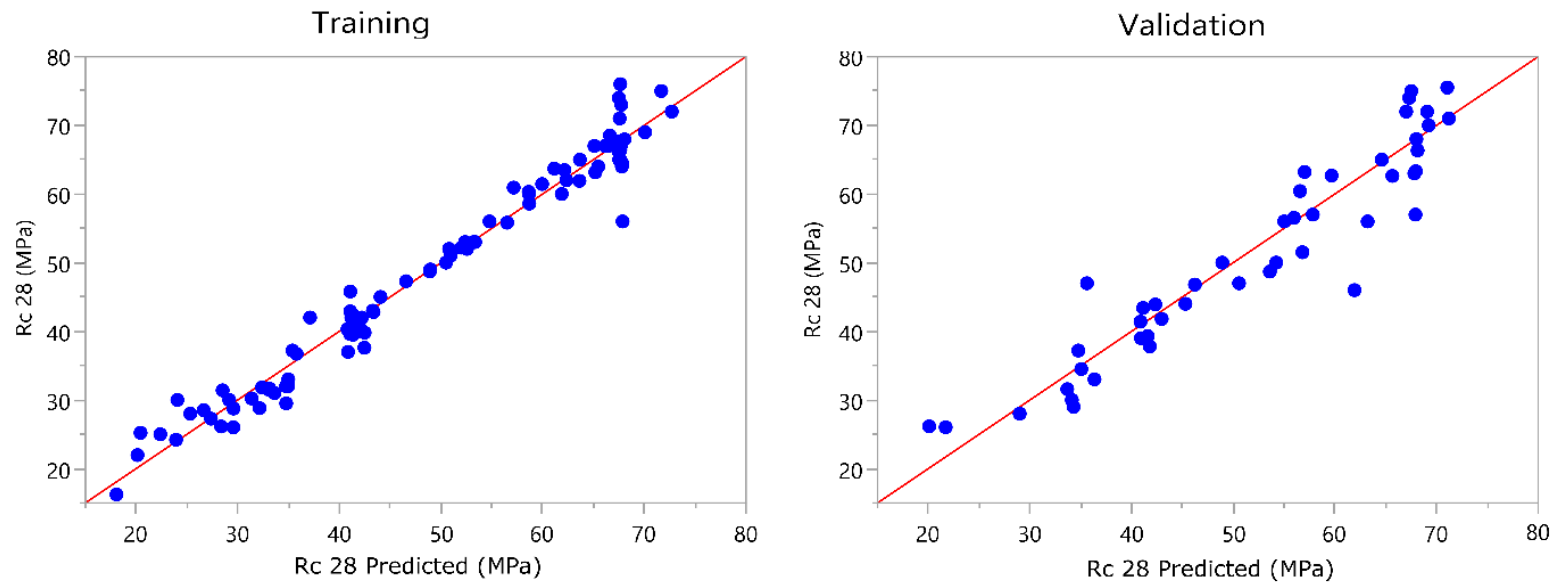

Figure 6: Regression for training and validation data results of Rc28
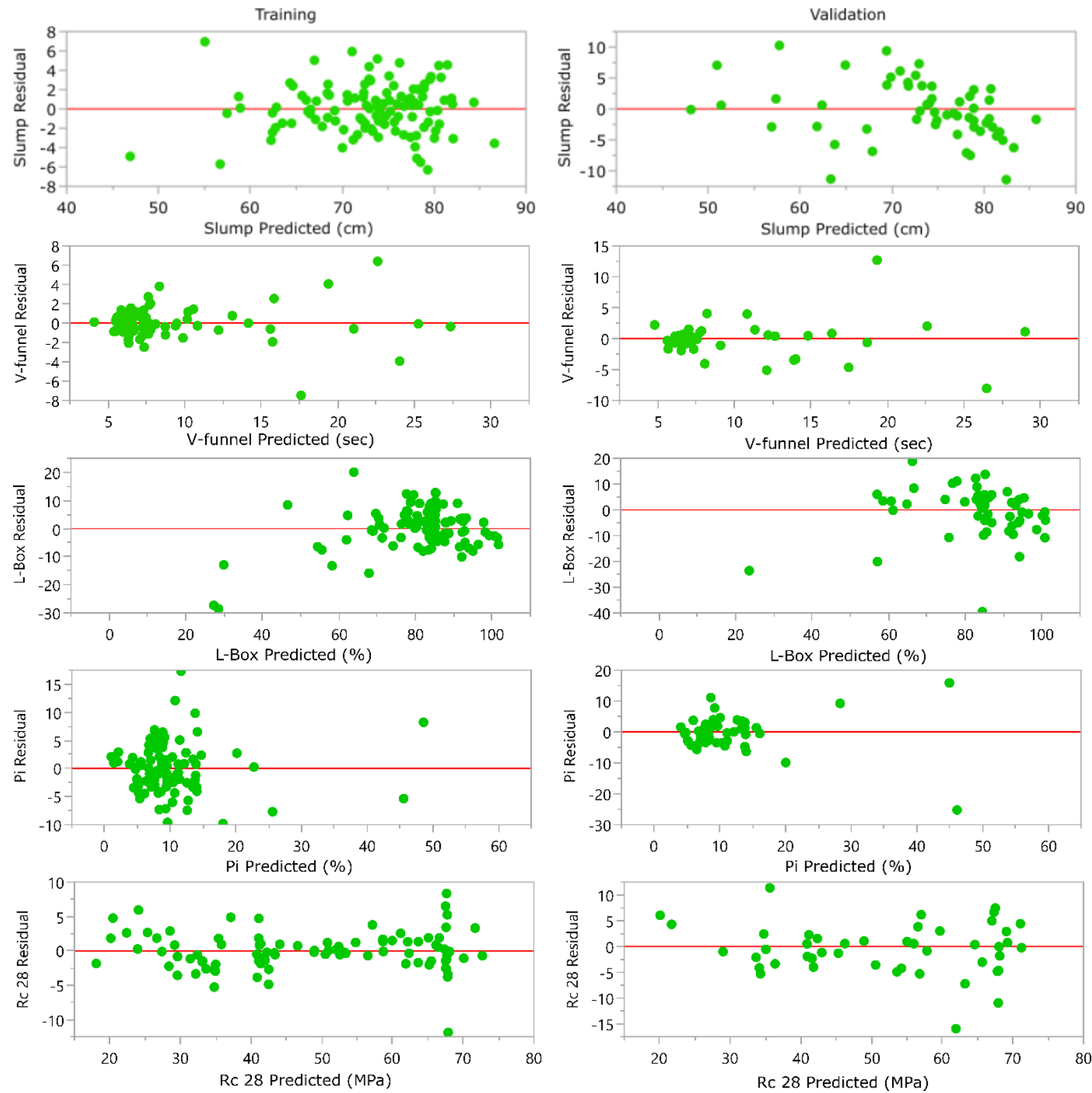

Figure 7: Residual by predicted plot for all models 


\section{Conclusion}

In this work, artificial neural networks accuracy in predicting SCC properties was assessed. For this purpose, an ANN models consisting of 5 hidden layer nodes, 12 input nodes which represent the components of SCC and 5 output nodes representing the fresh and hardened properties of SCC containing Algerian materials. Results conducted and presented in this paper demonstrate that the developed ANN models were able to predict 28 days with high accuracy as confirmed with Regression plots, residual analysis and statistical parameters. Furthermore, this modelling technique performs sufficiently in the estimation of Slump, L-Box and V-funnel time, while static stability could be predicted with acceptable precision. In general, ANNs can be considered as good technique in modelling and predicting of SCC properties with high reliability.

\section{References}

Ahmadi, M., Naderpour, H., \& Kheyroddin, A. (2017). ANN model for predicting the compressive strength of circular steel-confined concrete. International Journal of Civil Engineering, 15(2), 213-221.

Asteris, P. G., Kolovos, K. G., Douvika, M. G., \& Roinos, K. (2016). Prediction of self-compacting concrete strength using artificial neural networks. European Journal of Environmental and Civil Engineering, 20(sup1), s102-s122.

Belaidi, A. S. E., Azzouz, L., Kadri, E., \& Kenai, S. (2012). Effect of natural pozzolana and marble powder on the properties of self-compacting concrete. Construction and Building Materials, 31, 251-257.

Benabed, B. (2014). Influence de la qualité et de la nature des sables sur les performances et la durabilité des bétons autoplaçants. Université de Laghouat-Amar Telidji.

Benyamina, S., Menadi, B., Bernard, S. K., \& Kenai, S. (2019). Performance of self-compacting concrete with manufactured crushed sand. Advances in Concrete Construction, 7(2), 87.

Boukendakdji, O., Kenai, S., Kadri, E. H., \& Rouis, F. (2009). Effect of slag on the rheology of fresh selfcompacted concrete. Construction and Building Materials, 23(7), 2593-2598.

Boukhelkhal, A., Azzouz, L., Belaïdi, A. S. E., \& Benabed, B. (2016). Effects of marble powder as a partial replacement of cement on some engineering properties of self-compacting concrete. Journal of Adhesion Science and Technology, 30(22), 2405-2419.

Boukhelkhal, D., Boukendakdji, O., Kenai, S., \& Bachene, S. (2015). Effect of mineral admixture type on stability and rheological properties of self-compacting concrete.

Bouziani, T. (2013). Assessment of fresh properties and compressive strength of self-compacting concrete made with different sand types by mixture design modelling approach. Construction and Building Materials, 49, 308-314.

Douma, O. B., Boukhatem, B., Ghrici, M., \& Tagnit-Hamou, A. (2017). Prediction of properties of selfcompacting concrete containing fly ash using artificial neural network. Neural Computing and Applications, 28(1), 707-718.

Getahun, M. A., Shitote, S. M., \& Gariy, Z. C. A. (2018). Artificial neural network based modelling approach for strength prediction of concrete incorporating agricultural and construction wastes. Construction and Building Materials, 190, 517-525.

JMP. (2020). JMP Documentation Library, 1-5609. SAS Institute Inc. 2020. Discovering JMP® 15. Cary, NC: SAS Institute Inc. 
Laidani, Z. E.-A., Benabed, B., Abousnina, R., Gueddouda, M. K., \& Kadri, E.-H. (2020). Experimental investigation on effects of calcined bentonite on fresh, strength and durability properties of sustainable self-compacting concrete. Construction and Building Materials, 230, 117062.

Malagavelli, V., \& Manalel, P. A. (2014). Modeling of compressive strength of admixture-based self compacting concrete using fuzzy logic and artificial neural networks. Asian Journal of Applied Sciences. https://doi.org/10.3923/ajaps.2014.536.551

Nécira, B. (2018). Développement des bétons autoplaçants à hautes performances: influence de la composition. Université Mohamed Khider Biskra.

Nécira, B., Guettala, A., \& Guettala, S. (2017). Study of the combined effect of different types of sand on the characteristics of high performance self-compacting concrete. Journal of Adhesion Science and Technology, 31(17), 1912-1928.

Okamura, H., \& Ouchi, M. (2003). Self-compacting concrete. Journal of Advanced Concrete Technology, $1(1), 5-15$.

Ouldkhaoua, Y., Benabed, B., Abousnina, R., \& Kadri, E.-H. (2019). Rheological properties of blended metakaolin self-compacting concrete containing recycled CRT funnel glass aggregate. EpitoanyagJournal of Silicate Based \& Composite Materials, 71(5).

Saha, P., Prasad, M. L. V, \& RathishKumar, P. (2017). Predicting strength of SCC using artificial neural network and multivariable regression analysis. Comput. Concrete, 20(1), 31-38.

Sahraoui, M., \& Bouziani, T. (2019a). Effect of coarse aggregates and sand contents on workability and static stability of self-compacting concrete. Advances in Concrete Construction, 7(2), 97.

Sahraoui, M., \& Bouziani, T. (2019b). Effects of fine aggregates types and contents on rheological and fresh properties of SCC. Journal of Building Engineering, 26, 100890.

Skender, Z., Bali, A., \& Kettab, R. (2019). Self-compacting concrete (SCC) behaviour incorporating limestone fines as cement and sand replacement. European Journal of Environmental and Civil Engineering, 1-22.

Sonebi, M., Grünewald, S., Cevik, A., \& Walraven, J. (2016). Modelling fresh properties of self-compacting concrete using neural network technique. Computers and Concrete, 18(4), 903-920.

Thakre, N., Mangrulkar, D., Janbandhu, M., \& Saxena, J. (2017). Self-Compacting Concrete-Robustness of SCC. International Journal of Advanced Engineering Research and Science, 4(3), 237086.

Yaman, M. A., Abd Elaty, M., \& Taman, M. (2017). Predicting the ingredients of self compacting concrete using artificial neural network. Alexandria Engineering Journal, 56(4), 523-532.

YH aissa, Y., Idriss, G., \& Benabed, B. (2019). Mix-design and properties of self-compacting concrete made with calcareous tuff. Journal of Building Engineering, 27, 100997. https://doi.org/10.1016/j.jobe.2019.100997. 